\title{
Effects of temperature and plant diversity on orthopterans and leafhoppers in calcareous dry grasslands
}

\author{
Costanza Geppert ${ }^{1} \oplus \cdot$ Greta La Bella $^{1} \cdot$ Francesco Boscutti $^{2} \odot$ - Francesco Sanna ${ }^{1} \cdot$ Federico Marangoni $^{3}$. \\ Lorenzo Marini ${ }^{1}$ (D)
}

Received: 16 May 2020 / Accepted: 2 February 2021 / Published online: 22 February 2021

(c) The Author(s) 2021

\begin{abstract}
In mountains, current land-use changes are altering plant communities of semi-natural grasslands with potential cascading effects on associated herbivores. Besides vegetation changes, temperature is also a key driver of insect diversity, and in the European Alps is predicted to increase by $0.25{ }^{\circ} \mathrm{C}$ per decade. Understanding herbivore responses to temperature and plant composition changes in mountain environments is of increasing importance. Our study aims at investigating the response to temperature and plant diversity and composition of two key herbivore groups (orthopterans and leafhoppers) belonging to contrasting feeding guilds (chewers vs. sap-feeders). We hypothesized that orthopteran diversity would be driven by temperature while leafhoppers by plant community composition. We selected 15 dry calcareous grasslands ranging from 100 to $1330 \mathrm{~m}$ a.s.l. along two independent gradients of plant diversity and temperature. We sampled orthopteran and leafhopper species richness and abundance by sweep-netting. Consistent with their low feeding specialisation, orthopteran species richness and community composition were only driven by temperature. By contrast, leafhopper species richness was not affected by temperature nor by plant diversity but leafhopper community composition was strongly influenced by plant species composition. This response can be explained by the higher host feeding specialisation of many leafhopper species. Species rarity and mobility did not change the response of the diversity of both groups, but orthopteran abundance increased with temperature only for highly mobile species. Altogether, our results suggest that future responses of grassland herbivores to vegetation changes and temperature warming are highly variable and depend on the feeding strategy and specialisation of the focal herbivore group.

Implications for insect conservation Leafhoppers emerged to be particularly sensitive to potential management or climateinduced change in vegetation composition, while orthopterans are expected to respond directly to temperature warming due to their relaxed association with plant community diversity and composition.
\end{abstract}

Keywords Climate $\cdot$ Elevation $\cdot$ Feeding specialisation $\cdot$ Global change $\cdot$ Herbivores $\cdot$ Mountain

\section{Introduction}

CostanzaGeppert and Greta La Bella have contributed equally to this work.

Costanza Geppert

costanzageppert@gmail.com

1 DAFNAE, University of Padova, Viale dell'Università 16, 35020 Legnaro, Padova, Italy

2 Di4A-Department of Agricultural, Food, Environmental and Animal Sciences, University of Udine, Via delle Scienze 91, 33100 Udine, Italy

3 Museo Civico di Rovereto, Borgo Santa Caterina, 41, 38068 Rovereto, Trento, Italy
In the last decades, the loss and deterioration of speciesrich, semi-natural grasslands has been a major conservation problem throughout Europe (Hodgson et al. 2005; Poschlod and WallisDeVries 2002; van Dijk 1991). In the European Alps, traditionally managed grasslands host highly diverse communities of flora and fauna but are also increasingly under threat by global changes such as management intensification, abandonment of low-intensity grazing, landscape simplification and climate change (Dirnböck et al. 2003; Hinojosa et al. 2016; Humbert et al. 2009; Monteiro et al. 2011; Tasser and Tappeiner 2002; Tattoni et al. 2017). In mountains, many plant species respond to climate warming 
by moving to higher elevations reshuffling local plant communities (Lenoir et al. 2008). Both climate and local management changes often result in shifts in plant community composition and in the loss of plant diversity (Marini et al. 2009a) with potential cascading effects on associated insect diversity (Van der Putten et al. 2010).

A large body of research reports a strong bottom-up effect of plant composition and diversity on herbivore communities (Deraison et al. 2015; Moreira et al. 2016). Highly diverse plant communities are often more productive than speciespoor communities and should provide a greater diversity of shelter and reproduction sites as well as food resources, thereby favouring a larger number of consumers (Moreira et al. 2016). Consequently, altering grassland vegetation and reducing plant richness can lead to the loss of arthropod consumers, such as grasshopper, butterfly and bee species (Kruess and Tscharntke 2002; Marini et al. 2007, 2009b). However, plant-herbivore diversity relationship does not follow a general pattern but also depends on herbivore specialisation and feeding guild (Joshi et al. 2008; LaRose et al. 2020; Rodríguez-Castañeda et al. 2010). Low-mobile and specialised herbivores are more likely to be strongly affected by changes in plant composition, whereas the diversity of generalists should exhibit weaker responses because they are less limited to feed on specific host plants (Jactel and Brockerhoff 2007; Koricheva et al. 2000).

In montane ecosystems, besides vegetation diversity and composition, temperature is one of the main factors influencing insect herbivore diversity (Bale et al. 2002; McCain and Grytnes 2010). Low temperatures may directly affect species distribution by limiting physiological processes or indirectly constrain population size via reduced plant productivity (Bale et al. 2002). Hence, the rapid temperature changes over short geographical distances associated with elevational gradients are expected to influence arthropod species community and diversity (Körner 2007; Sundqvist et al. 2013). Herbivore species richness is generally expected to decline with elevation (Bale et al. 2002). However, due to the interdependence of moisture, temperature, exposition and altitude, the observed elevational patterns in species richness are complex and may vary among feeding guilds, taxonomic groups and regions (Bale et al. 2002; Hodkinson 2005; Rodríguez-Castañeda et al. 2010). As in the European Alps, a $1.5^{\circ} \mathrm{C}$ warming $\left(0.25{ }^{\circ} \mathrm{C}\right.$ per decade $)$ is expected in the first half of the 21st century (Gobiet et al. 2014), understanding herbivore response to temperature is of increasing importance.

Besides the environmental pressures explained above, species traits are also expected to influence species' sensitivity to environmental changes such as climate and land-use change (Matenaar et al. 2015). First, mobility appears as a strong predictor of success or decline of insect populations (Kotiaho et al. 2005), as varying mobility might affect how the species respond to variations in habitat area and quality (Shen et al. 2009). In general, poor dispersers seem to be more prone to extinction and range contractions imposed by several human-induced pressures such as fragmentation or eutrophication (Marini et al. 2010; Reinhardt et al. 2005). Second, also rarity may influence species' sensitivity as species that have narrower range are expected to be lost more frequently as a result of land-use change compared with species with broader habitat affinities and range (Sykes et al. 2020).

In this context, our study aims to investigate the response to temperature and plant diversity and composition of two key herbivore groups (Auchenorrhyncha, hereafter referred to as leafhoppers; and Orthoptera specialised in grassland environments, hereafter referred to as orthopterans) in dry calcareous grasslands. We selected them as model organisms because they both play an important role in grassland ecosystems (Deraison et al. 2015) and due to their ecological differences. Leafhoppers are a very abundant and diversified group of sap-feeders showing different degrees of host plant specialisation from strictly monophagous to polyphagous species (Biedermann et al. 2005). In contrast, orthopteran species are generalist chewers able to feed on many plant species, and are a fundamental component of arthropod communities in grasslands (Alignan et al. 2018; Branson et al. 2006). In addition, in Europe, Orthoptera are often thermophilic and are expected to be particularly sensitive to temperature changes (Fontana 2002; Schmitz et al. 2016; Willott and Hassall 1998). Hence, they represent a good model group to study the effect of temperature. By selecting 15 dry calcareous grasslands under the same extensive management, similar rainfall conditions and surrounding landuse, but along two independent gradients of plant diversity and temperature we addressed the following questions: (1) Does herbivore diversity increase with temperature? (2) Do shifts in plant composition and diversity explain variation in herbivore communities? (3) Do the two taxa belonging to contrasting feeding guilds exhibit a common response to these drivers? (4) Do herbivore responses to the considered drivers change depending on their regional rarity and mobility?

\section{Methods}

\section{Study area}

The study was carried out during spring-summer 2019 in the Natisone Valleys (Julian Prealps), in the South-Eastern Alps in Friuli Venezia Giulia region (NE Italy). In this area, the landscape is dominated by mixed broadleaf forests and, in lower proportion, by semi-natural grasslands within traditional agricultural landscape. Semi-natural dry grasslands 
in the study area are mowed once per year and host floristic communities with a high richness of sub-endemic and alpine species at the limit of their distribution range (Poldini 1995). Mean annual temperature at the lowest elevation in the study area is $12.46{ }^{\circ} \mathrm{C}$ (at $138 \mathrm{~m}$ a.s.1.) and $4.40{ }^{\circ} \mathrm{C}$ at the highest (1630 $\mathrm{m}$ a.s.l.), mean annual precipitation is ca. 1500-2300 mm.

\section{Sampling design}

We selected 15 sites ranging between 100 and $1330 \mathrm{~m}$ a.s.l. (Table S1, Figure S1). As the upper altitudinal limit for semi-natural calcareous dry grasslands is set at approximately $1300 \mathrm{~m}$ a.s.l., the selected range corresponded to the elevational distribution of this habitat (Festuco-Brometalia, Natura 2000 priority habitat, code 6210). The 15 selected grasslands were cut once a year and received no fertilizer applications. The lack of a management gradient allowed us to isolate the effect of different plant diversity across sites that did not differ in their management. All selected sites were dominated by Brachypodium rupestre, Bromopsis erecta and Festuca spp and characterized by a wide diversity of grasses and herbs. Along the elevational gradient, we placed data loggers at $1.5 \mathrm{~m}$ from the soil, to record air temperature every $30 \mathrm{~min}$. Air temperature was recorded approximately over 12 weeks (from mid-June to August) along the altitudinal gradient. Mean temperatures over the whole duration of the experiment ranged from c. $25.2{ }^{\circ} \mathrm{C}$ at the lowest elevation ( $100 \mathrm{~m}$ a.s.1.) to $17.1{ }^{\circ} \mathrm{C}$ at the highest elevation (1330 $\mathrm{m}$ a.s.1.). The selection of the sites was performed to keep statistical independence between plant diversity and temperature. Temperature and elevation were strongly correlated (Pearson correlation $r=-0.95$; $p<0.001)$, whereas temperature and plant species richness were not (Pearson correlation $\mathrm{r}=0.27 ; p=0.322$ ) as well as elevation and plant species richness (Pearson correlation $\mathrm{r}$ $=-0.274 ; p=0.323$ ).

As both herbivore groups are expected to be affected by the composition of the surrounding landscape (forest cover, Marini et al. 2009a, b; Walcher et al. 2017; landscape connectivity Rösch et al. 2013), we quantified the proportion of forest cover (dominant habitat in the study area) in a buffer of $500 \mathrm{~m}$ (diameter) around each sites. This variable was not related to both temperature (Pearson correlation $\mathrm{r}=0.04 ; p=0.889$ ) and plant diversity (Pearson correlation $\mathrm{r}=-0.40 ; p=0.112$ ). In preliminary analyses, we tested this variable and found no effect on both groups. Hence, we only present the effect of our local factors in the main text. vascular species and their cover present in a $12 \mathrm{~m} \times 3 \mathrm{~m}$ plot. Plant species nomenclature followed Poldini et al. (2001). In the selected sites, overall 175 plant species occurred ranging from a minimum of 22 to a maximum of 53 species per site (Table S2).

\section{Herbivore surveys}

Around the plot used for the plant surveys, insects were sampled approximately every two weeks starting from mid-May until the end of August, for a total of six rounds of sampling, in order to collect species with different phenology. We chose the sweep netting as sampling method, because it is widely adopted, quick and provides reliable estimates of relative abundance and species composition of both orthopteran and hemipteran communities in grasslands (Doxon et al. 2011; Gardiner et al. 2005). In each site, we sampled along two transects $25 \mathrm{~m}$ long, distant from each other about $6 \mathrm{~m}$. We performed 25 sweeps per transect, for a total of 50 sweeps per site. Surveys took place during the warmer hours of the day (between 10:00 and 18:00) on sunny days that did not follow a day of rainfall, and were carried out always by the same person (GLB). We preserved collected specimens into $70 \%$ ethanol and identified them at the species level in the laboratory. We followed Biedermann and Niedringhaus (2009); Della Giustina (2019); Vidano (1965); and Wagner (1951) for leafhoppers identification and nomenclature. Orthopterans were identified using Fontana (2002), we identified and counted only adult specimens. Based on Fontana (2002), we included only orthopteran species that are known to be specialized for grassland habitats. We excluded 10 Ensifera species for a total of 33 individuals. For each taxonomic group, the species richness referred to the pooled number of species. Following Matenaar et al. (2015), we assessed for each species two traits: mobility and regional rarity. These categories were chosen because likely associated with extinction risk for both herbivore groups (Marini et al. 2012; Öckinger et al. 2010; Rösch et al. 2013). Mobility was defined based on wing development, we classified both taxa in two categories: "macropterous" and "nonmacropterous". For orthopterans, non-macropterous species consisted in apterous, squamipterous and brachypterous species, while for leafhoppers only in brachypterous ones. Rarity was calculated based on species occurrence in the study sites, following Matenaar et al. (2015), a species was considered "rare" when present in less than 3 sites, "intermediate" in more than 2 and less than 5 sites, and "common" in more than 4 sites.

\section{Plant surveys}

In each site, we performed a floristic survey at the end of May, before the mowing. It consisted in the assessment of all 


\section{Statistical analyses}

\section{Diversity patterns of orthopteran and leafhopper communities}

All analyses were conducted with the Software R version 3.6.1 (Core Team 2017). We used linear models to estimate the effects of temperature and plant species richness on orthopteran and leafhopper communities. For each taxon, models included as response variables the pooled number of species and abundance observed during the six sampling rounds. In addition, we used linear models to test if the two taxa responded differently to temperature and plant species richness depending on their mobility and rarity. First, for each taxon, we tested the effect of temperature and plant species richness separately for rare, intermediate and common species, using the pooled number of species and then, their abundance as response variables. Second, for each taxon, for macropterous and non-macropterous species separately, we tested the effect of temperature and species richness on their pooled number of species and abundance. For all models, to improve the linearity and residuals distribution, all response variables were log-transformed. Normality of the residuals was visually evaluated with q-q plots using the "car" package (Fox et al. 2012). Although our response variables were counts, we did not present the results from generalized linear models (both Poisson and negative binomial distribution) due to the poor outcome of model diagnostics compared to linear models. For each model, we tested for spatial correlation in the residuals using Moran's I and we did not find any significant spatial autocorrelation.

\section{Plant composition effects on orthopteran and leafhopper communities}

To investigate the effects of temperature and plant community composition on the composition of orthopteran and leafhopper communities, we performed multiple regression on distance matrices (Lichstein 2007). First, based on presence/ absence matrices, we calculated for each taxon (i.e. plants, orthopterans, leafhoppers) a distance matrix using Jaccard dissimilarity index (Legendre 2014), with the "vegdist" function in the "vegan" package (Oksanen et al. 2019). Second, we generated a temperature distance matrix using the "vegdist" function with Euclidean distance. Then, we performed regressions on distance matrices using the "MRM" function in the "ecodist" package (Goslee and Urban 2007), and tested the effects of plant dissimilarity and temperature distance on leafhopper and orthopteran dissimilarity, separately. We also calculated Bray-Curtis dissimilarity matrices using the "vegdist" function based on leafhopper and orthopteran abundance and on plant cover but, as results were consistent with the one obtained using presence absence matrices, we do not present them in the text.

To visualize the relationship between temperature and single species of orthopterans and leafhoppers, we run a principal component analysis (PCA). We performed a PCA using the function "prcomp" on abundance matrices transformed using logarithmic transformation as suggested by Anderson et al. (2006).

In preliminary analyses, using a Mantel test with the function "mantel" in the "vegan" package (Oksanen et al. 2019), we tested whether dissimilarity in orthopteran or leafhopper composition varied with increasing geographical distance. For both groups, we found no effect of distance (for orthopterans $\mathrm{r}=-0.253, p=0.980$, for leafhoppers $\mathrm{r}=0.094, p=0.226$ ).

\section{Results}

\section{Orthopteran communities}

Overall, we found 31 species of orthopterans, ranging from 4 to 12 species per site, and 940 individuals (918 individuals identified to the species level, Table S3). The most abundant species was Micropodisma salamandra ( $43 \%$ of total abundance) followed by Chorthippus parallelus (13\%). Results of the linear model revealed that temperature was the only driving factor of orthopteran species richness (Fig. 1; Table 1). We found a linear positive relationship between species richness and temperature. Orthopteran abundance did not respond to temperature nor to plant species richness

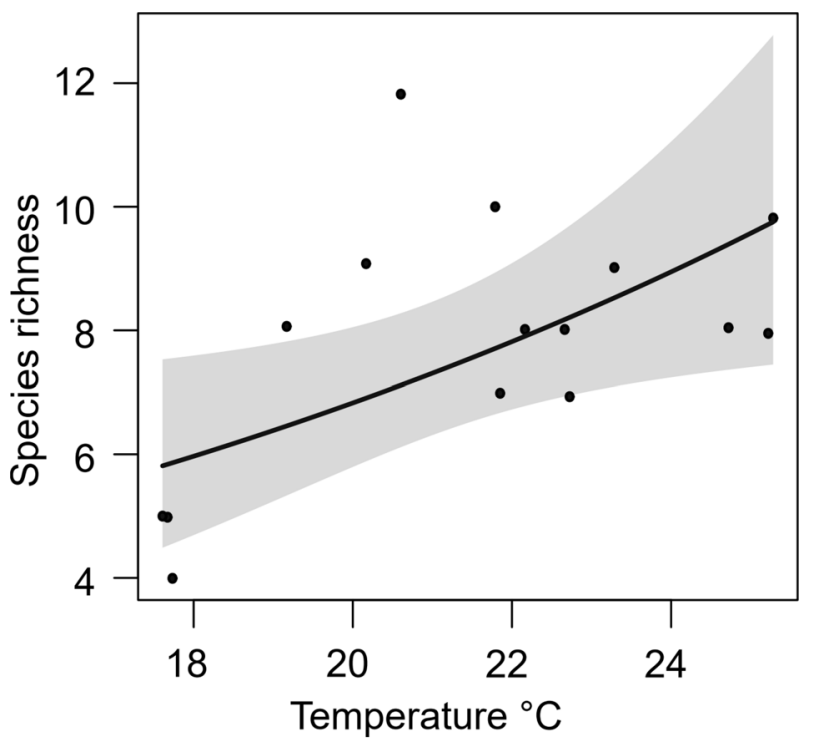

Fig. 1 Effect of temperature on orthopteran species richness. Line indicates model predicted values, shading shows $95 \%$ CI 
Table 1 Results from linear models testing the effects of temperature and plant species richness on species richness and abundance of (a) orthopterans and (b) leafhoppers

\begin{tabular}{lrrrr}
\hline Response variable & Estimate & $\mathrm{SE}$ & $\mathrm{t}$ & $\mathrm{p}$ \\
\hline $\begin{array}{l}\text { (a) Orthopterans } \\
\text { Species richness }\end{array}$ & & & & \\
$\quad$ Temperature & 0.067 & 0.026 & 2.555 & 0.025 \\
$\quad$ Plant species richness & 0.001 & 0.007 & 0.113 & 0.914 \\
Abundance & & & & \\
$\quad$ Temperature & 0.060 & 0.075 & 0.794 & 0.443 \\
$\quad$ Plant species richness & 0.030 & 0.022 & 1.276 & 0.226 \\
(b) Leafhoppers & & & & \\
$\quad$ Species richness & & & & \\
$\quad$ Temperature & 0.042 & 0.049 & 0.870 & 0.401 \\
$\quad$ Plant species richness & -0.009 & 0.015 & -0.638 & 0.536 \\
Abundance & & & & \\
$\quad$ Temperature & 0.139 & 0.084 & 1.644 & 0.126 \\
$\quad$ Plant species richness & 0.008 & 0.025 & 0.302 & 0.768 \\
\hline
\end{tabular}

(Table 1). Responses of abundance and species richness to both considered drivers did not change based on orthopteran rarity (Table S5). Responses of species richness did not change based on orthopteran mobility but the abundance of macropterous species increased with temperature, while the abundance of non-macropterous species did not (Table S6). Multiple regression on distance matrices showed that temperature distance affected orthopteran community dissimilarity, while plant community dissimilarity did not have any effect (Fig. 2a; Table 2). The PCA analysis extracted 33.23,

a) Orthopterans

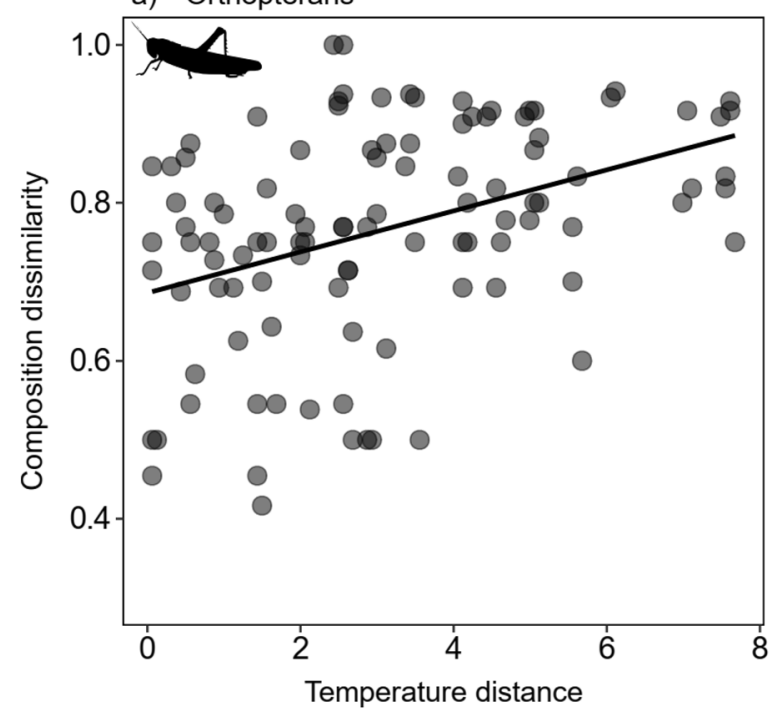

Fig. 2 Effect of a temperature distance on orthopteran dissimilarity and b plant community dissimilarity on leafhopper dissimilarity. Composition dissimilarity was calculated using Jaccard index (Leg-
19.27 , and $11.22 \%$ of the variance with the first three components, respectively (Fig. 3a). Micropodisma salamadra most contributed to the first principal component, while Chorthippus parallelus to the second. Omocestus rufipes, Euchorthippus declivus and Glyptobothrus mollis were more closely associated with warmer temperatures. By contrast, Gomphocerippus rufus and Mecostethus parapleurus were related to colder temperatures.

\section{Leafhopper communities}

Overall, we found 82 species and 2468 individuals of leafhoppers (2405 individuals identified at the species and at the genus level and the remaining at the family level, Table S4). Most common species were Jassargus obtusivalvis (19\%) and Philaenus spumarius (9\%). Neither leafhopper species richness nor abundance responded to temperature or plant species richness (Table 1). In addition, responses of species richness and abundance to both considered drivers did not change based on leafhopper mobility nor rarity (Tables S5 and S6). Moreover, multiple regression on distance matrices indicated strong differences in leafhopper community composition among sites with dissimilar composition of plant communities, while temperature distance had no effect (Fig. 2b; Table 2). Results from the PCA analysis show that $22.85,17.71$, and $16.25 \%$ of the variation is explained by the first three axes, respectively, for a cumulative total of $56.81 \%$ of variance explained (Fig. 3b). Jassargus flori most contributed to the first principal component while Adarrus multinotatus to the second. Dicranotropis hamata and

\section{b) Leafhoppers}

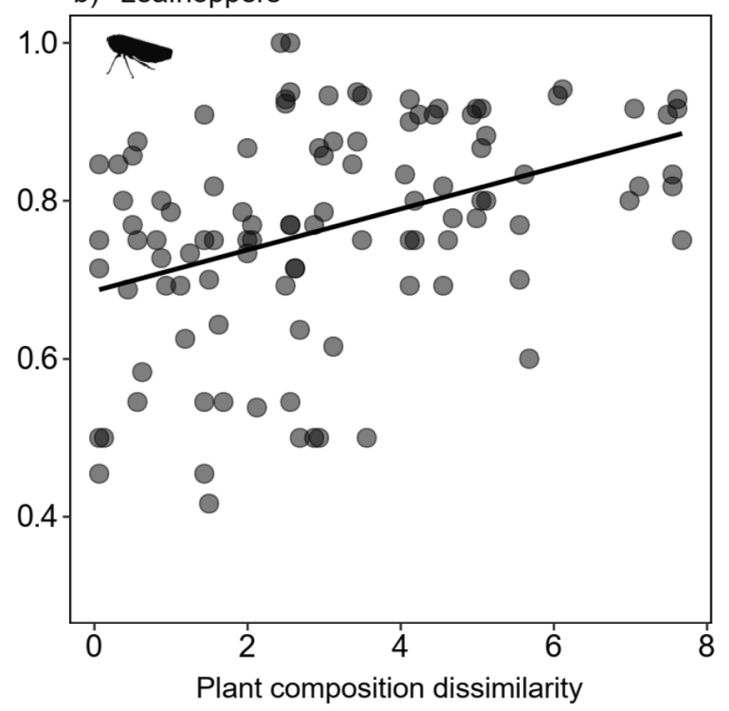

endre 2014). Regression lines are estimated from multiple regression models on distance matrices, only significant results are shown 
Table 2 Results from multiple regression models on distance matrices testing the effects of temperature distance and plant composition dissimilarity on composition dissimilarity of orthopterans and leafhoppers

\begin{tabular}{|c|c|c|c|c|}
\hline Response variable & $\begin{array}{l}\text { Explanatory vari- } \\
\text { ables }\end{array}$ & $\mathrm{R}^{2}$ & Estimate & $\mathrm{p}$ \\
\hline \multirow[t]{2}{*}{$\begin{array}{l}\text { Orthopteran dis- } \\
\text { similarity }\end{array}$} & $\begin{array}{l}\text { Temperature dis- } \\
\text { tance }\end{array}$ & 0.159 & 0.025 & 0.006 \\
\hline & Plant dissimilarity & & 0.080 & 0.721 \\
\hline \multirow[t]{2}{*}{$\begin{array}{l}\text { Leafhopper dissimi- } \\
\text { larity }\end{array}$} & $\begin{array}{l}\text { Temperature dis- } \\
\text { tance }\end{array}$ & 0.261 & 0.008 & 0.112 \\
\hline & Plant dissimilarity & & 0.462 & 0.001 \\
\hline
\end{tabular}

Distance matrices for plants, orthopterans and leafhoppers were calculated using Jaccard dissimilarity index (Legendre 2014), while temperature distance using Euclidean distance

Forcipata citrinella showed a closer association to warmer temperatures.

\section{Discussion}

In dry calcareous grasslands, we investigated the effects of temperature, plant species richness and composition on two key herbivore groups with different specialisation and belonging to contrasting feeding guilds. We found that orthopteran species richness as well as species composition were driven by temperature, while leafhopper richness was affected neither by temperature nor by plant diversity. However, leafhopper community composition was strongly influenced by plant composition. Species rarity and mobility did not change the response of the diversity of both groups, but orthopteran abundance increased with temperature only for highly mobile species. Altogether, our results show that herbivore responses to shift in plant composition and temperature are highly variable and depend on the feeding specialisation of the focal herbivore group.

\section{Orthopteran communities}

Orthopteran species richness increased with increasing temperatures. Moreover, as sites became more dissimilar in terms of temperature (i.e. low vs. high elevation sites), orthopteran communities became also more dissimilar in terms of species composition. These results are consistent with other studies reporting detrimental effects of colder temperatures on orthopteran diversity along elevational gradients (Descombes et al. 2017; Kati et al. 2012). Most orthopteran species are thermophilic and low temperatures limit all their key physiological processes, thus determining a reduced performance and fitness (Schmitz et al. 2016; Willott and Hassall 1998). In particular, Omocestus rufipes, Euchorthippus declivus and Glyptobothrus mollis were more closely associated with warmer temperatures. The latter two species are xerophilous, typical of dry grasslands, while Omocestus rufipes is a more generalist termophilous species (Fontana 2002). By contrast, Gomphocerippus rufus and Mecostethus parapleurus that were related to colder temperatures, are usually found in colder and wetter environments. We cannot exclude that temperatures were also associated with moisture, that plays a fundamental role in the embryonic development and hatching of orthopterans (Powell et al. 2007). Moreover, temperature affected orthopteran abundance differently depending on their mobility. We found that the abundance of mobile species increased with increasing temperature,

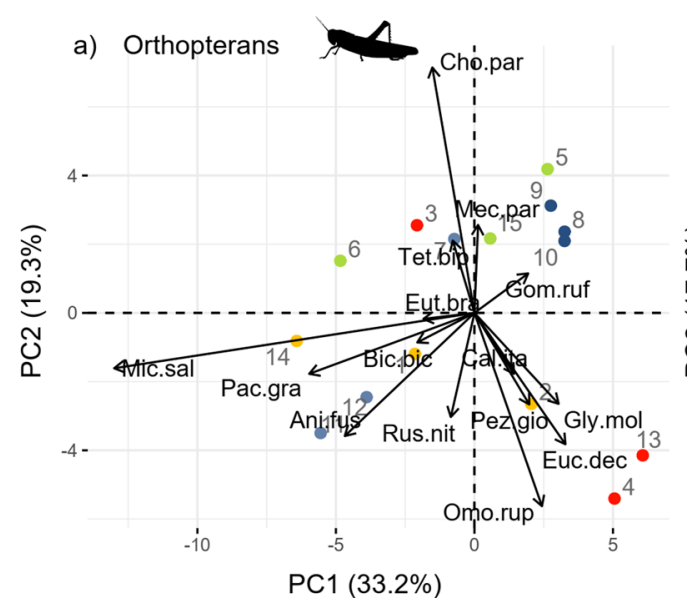

Fig. 3 Results of the Principal Component Analysis (PCA) carried out on the 15 sites $\mathbf{a}$ on orthopteran and $\mathbf{b}$ on leafhopper species. Only the fifteen species with a large value of $\cos ^{2}$ and therefore contributing the most to the construction of the axes are shown (Kas-

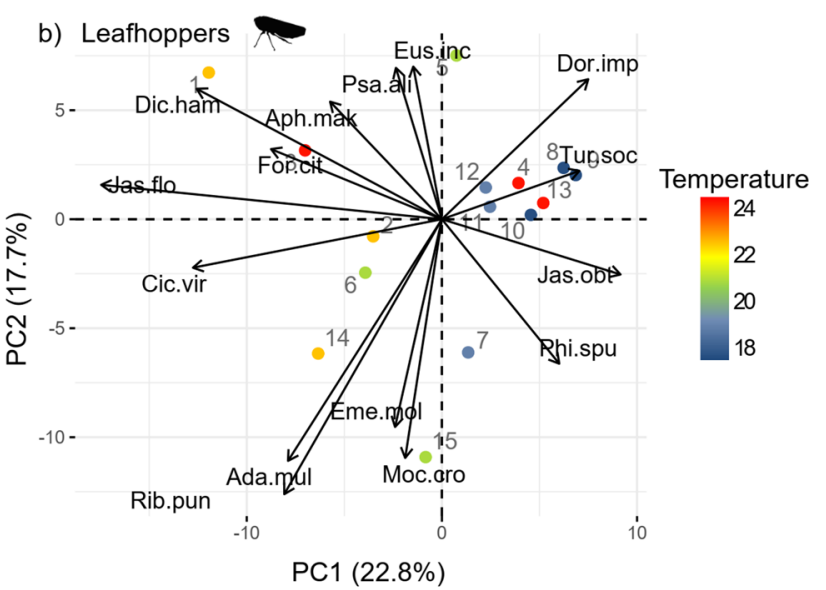

sambara and Mundt 2017). To enable a clearer visualization, species names are abbreviated showing only the first three letters of genus and species names. Full names are available in Tables S3 and S4 
while sedentary species' abundance did not respond to temperature. Highly mobile species are expected to be less affected by barriers, because they are better at occupying suitable habitats compared with sedentary species (Marini et al. 2012). This result supports other studies where mobility appears as a strong predictor of widespread success of insect populations (Kotiaho et al. 2005). Contrary to temperature, plant diversity and plant composition did not affect orthopteran species richness, abundance or community composition. Orthoptera are generally associated with vegetation characteristics, such as vegetation structure and plant nutrient contents (Miao et al. 2018; Unsicker et al. 2010). In fact, vegetation structure determines the availability of microsites for oviposition, shelter to escape from natural enemies and food resources ( $\mathrm{Zhu}$ et al. 2017). However, as they are generalist chewers, orthopterans depend more on the amount of resources than on plant identity (Perner et al. 2005). Therefore, plant richness or composition seem to be weak predictors of orthopteran diversity, while other factors such as temperature but also vegetation structure, management intensity, vegetative litter amount and soil type might act as drivers of their distribution (Helbing et al. 2014; Kruess and Tscharntke 2002; Löffler and Fartmann 2017; Marini et al. 2007; Miao et al. 2018; Nickel and Hildebrandt 2003a; Schirmel et al. 2011; Torrusio et al. 2002; Walcher et al. 2017).

\section{Leafhopper communities}

We did not find any effect of temperature and plant species richness on leafhopper communities. Leafhoppers responded only to plant community composition indicating a strong link between plant and leafhopper species identity. Most leafhoppers are specialist sap-feeders that show a strong dependency on their host plants (Nickel and Hildebrandt 2003b). Therefore, it is the plant species identity that determines which leafhopper species can occur in a site (Perner et al. 2005; Taft and Dietrich 2017). Leafhopper dependency on vegetation composition emerged also from other studies showing a positive relationship between host plant and leafhopper species richness (Koricheva et al. 2000; Rösch et al. 2013; Scherber et al. 2010). Here, different plant communities also provided different microclimatic conditions and sites for shelter, oviposition or overwintering, hence favouring a more diverse number of consumers (Helbing et al. 2017). Altogether these results suggest that habitat quality and, in particular, plant species composition (i.e. the identity of plant species in a community) might play a more important role than temperature in driving patterns of species composition of specialist herbivores such as leafhoppers (Chisté et al. 2018; Everwand et al. 2014; Helbing et al.
2017; Koricheva et al. 2000; Poniatowski et al. 2018). In fact, except for some species as the thermophilous Dicranotropis hamata, leafhopper species showed a weak association with temperature. An alarming consequence of leafhopper reliance on vegetation composition is that any management practice such as fertilization, mowing or grazing, that modifies vegetation composition and, in particular, intensive practices, will have a strong negative effect on leafhopper communities (Biedermann et al. 2005; Helden et al. 2015; Kőrösi et al. 2012).

\section{Conclusions}

In dry calcareous grasslands, insect herbivores exhibiting different feeding specialisation showed contrasting responses to temperature and shifts in plant species composition. For the persistence of specialist sap-feeder insects, the relevance of habitat quality and, in particular, of plant community composition clearly emerged (Anthes et al. 2003; Bauerfeind et al. 2009; Biedermann et al. 2005; Löffler and Fartmann 2017; Münsch et al. 2019; Samways and Lu 2007). Our results show that, even with no loss of plant diversity, shifts in plant composition strongly modified the assembly of leafhopper species communities. This suggests the importance of studying variation in species composition besides the more common approach of only considering species richness. By contrast, orthopterans, that are generalist chewers, were not affected by plant composition but were limited by colder temperatures (Descombes et al. 2017; Schmitz et al. 2016). Any management actions affecting plant composition should consider these differential responses driven by the feeding specialisation of the focal herbivore group (Vehviläinen et al. 2007). Moreover, in the context of climate change, we expect leafhoppers to be particularly sensitive to potential climate-induced shifts in vegetation composition, while orthopterans are expected to respond directly to temperature warming due to their relaxed association with plant community diversity and composition.

Supplementary Information The online version contains supplementary material available at https://doi.org/10.1007/s10841-021-00300-3.

Acknowledgements The research was supported by the University of Padua STARS Consolidator Grant (STARS-CoG-324 2017, project BICE) to LM. We thank Daria Corcos and Vittoria de Marchi for help during fieldwork. We are grateful to the farmers of the association 'Kmecka zveza' and the municipality of Savogna (UD) that allowed us to perform the study on their land. We thank Thomas Zuna-Kratky and two anonymous reviewers for their insightful comments.

Funding Open access funding provided by Università degli Studi di Padova within the CRUI-CARE Agreement. 
Data availability Data analysed for this study is available at: https:// doi.org/10.1007/s10841-021-00300-3.

Open Access This article is licensed under a Creative Commons Attribution 4.0 International License, which permits use, sharing, adaptation, distribution and reproduction in any medium or format, as long as you give appropriate credit to the original author(s) and the source, provide a link to the Creative Commons licence, and indicate if changes were made. The images or other third party material in this article are included in the article's Creative Commons licence, unless indicated otherwise in a credit line to the material. If material is not included in the article's Creative Commons licence and your intended use is not permitted by statutory regulation or exceeds the permitted use, you will need to obtain permission directly from the copyright holder. To view a copy of this licence, visit http://creativecommons.org/licenses/by/4.0/.

\section{References}

Alignan JF, Debras JF, Dutoit T (2018) Orthoptera prove good indicators of grassland rehabilitation success in the first French Natural Asset Reserve. J Nat Conserv 44:1-11. https://doi.org/10.1016/j. jnc.2018.04.002

Anderson MJ, Ellingsen KE, McArdle BH (2006) Multivariate dispersion as a measure of beta diversity. Ecol Lett 9:683-693. https:// doi.org/10.1111/j.1461-0248.2006.00926.x

Anthes N, Fartmann T, Hermann G, Kaule G (2003) Combining larval habitat quality and metapopulation structure-the key for succesful management of pre-alpine Euphydryas aurinia colonies. J Insect Conserv 7:175-185. https://doi.org/10.1023/A:10273 30422958

Bale JS, Masters GJ, Hodkinson ID, Awmack C, Bezemer TM, Brown VK, Butterfield J, Buse A, Coulson JC, Farrar J, Good JEG, Harrington R, Hartley S, Jones TH, Lindroth RL, Press MC, Symrnioudis I, Watt AD, Whittaker JB (2002) Herbivory in global climate change research: direct effects of rising temperature on insect herbivores. Glob Chang Biol 8:1-16. https://doi.org/10.10 46/j.1365-2486.2002.00451.x

Bauerfeind SS, Theisen A, Fischer K (2009) Patch occupancy in the endangered butterfly Lycaena helle in a fragmented landscape: effects of habitat quality, patch size and isolation. J Insect Conserv 13:271-277. https://doi.org/10.1007/s10841-008-9166-1

Biedermann R, Achtziger R, Nickel H, Stewart AJA (2005) Conservation of grassland leafhoppers: a brief review. J Insect Conserv 9:229-243. https://doi.org/10.1007/s10841-005-0531-z

Biedermann R, Niedringhaus R (2009) The plant-and leafhoppers of Germany: identification key to all species. WABV Fründ, Scheeßel

Branson DH, Joern A, Sword GA (2006) Sustainable management of insect herbivores in grassland ecosystems: new perspectives in grasshopper control. Bioscience. https://doi.org/10.1641/00063568(2006)56[743:SMOIHI]2.0.CO;2

Chisté MN, Mody K, Kunz G, Gunczy J, Blüthgen N (2018) Intensive land use drives small-scale homogenization of plant- and leafhopper communities and promotes generalists. Oecologia 186:529540. https://doi.org/10.1007/s00442-017-4031-0

Core Team R (2017) R: language and environment for statistical computing [WWW document]. R Foundation for Statistical Computing, Vienna

Della Giustina W (2019) Faune de france 100. Les Delphacidae de France ed des pays limitrophes (Hemiptera, Fulgoromorpha). Fédération française des sociétés de sciences naturelles, Paris

Deraison H, Badenhausser I, Loeuille N, Scherber C, Gross N (2015) Functional trait diversity across trophic levels determines herbivore impact on plant community biomass. Ecol Lett 18:1346-1355. https://doi.org/10.1111/ele.12529

Descombes P, Marchon J, Pradervand JN, Bilat J, Guisan A, Rasmann S, Pellissier L (2017) Community-level plant palatability increases with elevation as insect herbivore abundance declines. J Ecol 105:142-151. https://doi.org/10.1111/1365-2745.12664

Dirnböck T, Dullinger S, Grabherr G (2003) A regional impact assessment of climate and land-use change on alpine vegetation. J Biogeogr 30:401-417. https://doi.org/10.1046/j.1365-2699.2003.00839

Doxon ED, Davis CA, Fuhlendorf SD (2011) Comparison of two methods for sampling invertebrates: vacuum and sweepnet sampling. J F Ornithol 82:60-67. https://doi.org/10.111 1/j.1557-9263.2010.00308.x

Everwand G, Rösch V, Tscharntke T, Scherber C (2014) Disentangling direct and indirect effects of experimental grassland management and plant functional-group manipulation on plant and leafhopper diversity. BMC Ecol 14:1-12. https://doi. org/10.1186/1472-6785-14-1

Fontana P (2002) Guida al riconoscimento e allo studio di cavallette, grilli, mantidi e insetti affini del Veneto : Blattaria, Mantodea, Isoptera, Orthoptera, Phasmatodea, Dermaptera, Embiidina. Museo Naturalistico Archeologico di Vicenza, Vicenza

Fox J, Weisberg S, Bates D, Firth D, Friendly M, Gor- G, Graves S, Heiberger R, Laboissiere R, Mon- G, Nilsson H, Ogle D, Ripley B, Zeileis A (2012) The car Package. R 1-147

Gardiner T, Hill J, Chesmore D (2005) Review of the methods frequently used to estimate the abundance of Orthoptera in grassland ecosystems. J Insect Conserv 9:151-173. https://doi.org/10.1007/ s10841-005-2854-1

Gobiet A, Kotlarski S, Beniston M, Heinrich G, Rajczak J, Stoffel M (2014) 21st century climate change in the European Alps-a review. Sci Total Environ 493:1138-1151. https://doi. org/10.1016/j.scitotenv.2013.07.050

Goslee SC, Urban DL (2007) The ecodist package for dissimilarity-based analysis of ecological data. J Stat Softw. https://doi. org/10.18637/jss.v022.i07

Helbing F, Blaeser TP, Löffler F, Fartmann T (2014) Response of Orthoptera communities to succession in alluvial pine woodlands. J Insect Conserv 18:215-224. https://doi.org/10.1007/ s10841-014-9632-x

Helbing F, Fartmann T, Löffler F, Poniatowski D (2017) Effects of local climate, landscape structure and habitat quality on leafhopper assemblages of acidic grasslands. Agric Ecosyst Environ 246:94-101. https://doi.org/10.1016/j.agee.2017.05.024

Helden AJ, Mckenzie R, Cobbold G, Grice PV, Anderson GQA, MacDonald MA (2015) Field-based grassland management for cirl buntings (Emberiza cirlus L.) and its effect on plant- and leafhoppers (Hemiptera: Auchenorrhyncha). Insect Conserv Divers 8:272-281. https://doi.org/10.1111/icad.12106

Hinojosa L, Napoléone C, Moulery M, Lambin EF (2016) The "mountain effect" in the abandonment of grasslands: Insights from the French Southern Alps. Agric Ecosyst Environ 221:115-124. https://doi.org/10.1016/j.agee.2016.01.032

Hodgson JG, Grime JP, Wilson PJ, Thompson K, Band SR (2005) The impacts of agricultural change (1963-2003) on the grassland flora of Central England: processes and prospects. Basic Appl Ecol 6:107-118. https://doi.org/10.1016/j. baae.2005.01.009

Hodkinson ID (2005) Terrestrial insects along elevation gradients: species and community responses to altitude. Biol Rev 80:489. https ://doi.org/10.1017/S1464793105006767

Humbert JY, Ghazoul J, Walter T (2009) Meadow harvesting techniques and their impacts on field fauna. Agric Ecosyst Environ. https://doi.org/10.1016/j.agee.2008.11.014 
Jactel H, Brockerhoff EG (2007) Tree diversity reduces herbivory by forest insects. Ecol Lett 10:835-848. https://doi.org/10.111 1/j.1461-0248.2007.01073.x

Joshi J, Otway SJ, Koricheva J, Pfisterer AB, Alphei J, Roy BA, Scherer-Lorenzen M, Schmid B, Spehn E, Hector A (2008) Bottom-up effects and feedbacks in simple and diverse experimental grassland communities. Springer, Berlin, pp 115-135. https://doi. org/10.1007/978-3-540-74004-9_6

Kassambara A, Mundt F (2017) Package "factoextra" extract and visualize the results of multivariate data analyses. R Packag Version 1(5):337-354

Kati V, Zografou K, Tzirkalli E, Chitos T, Willemse L (2012) Butterfly and grasshopper diversity patterns in humid Mediterranean grasslands: the roles of disturbance and environmental factors. J Insect Conserv 16:807-818. https://doi.org/10.1007/s10841-012-9467-2

Koricheva J, Mulder CPH, Schmid B, Joshi J, Huss-Danell K (2000) Numerical responses of different trophic groups of invertebrates to manipulations of plant diversity in grasslands. Oecologia 125:271-282. https://doi.org/10.1007/s004420000450

Körner C (2007) The use of "altitude" in ecological research. Trends Ecol Evol 22:569-574. https://doi.org/10.1016/j.tree.2007.09.006

Kőrösi Á, Batáry P, Orosz A, Rédei D, Báldi A (2012) Effects of grazing, vegetation structure and landscape complexity on grassland leafhoppers (Hemiptera: Auchenorrhyncha) and true bugs (Hemiptera: Heteroptera) in Hungary. Insect Conserv Divers 5:57-66. https://doi.org/10.1111/j.1752-4598.2011.00153.x

Kotiaho JS, Kaitala V, Komonen A, Päivinen J (2005) Predicting the risk of extinction from shared ecological characteristics. Proc Natl Acad Sci USA 102:1963-1967. https://doi.org/10.1073/ pnas.0406718102

Kruess A, Tscharntke T (2002) Grazing intensity and the diversity of grasshoppers, butterflies, and trap-nesting bees and wasps. Conserv Biol 16:1570-1580. https://doi.org/10.104 6/j.1523-1739.2002.01334.x

LaRose JP, Webb EB, Finke DL (2020) Comparing grasshopper (Orthoptera: Acrididae) communities on tallgrass prairie reconstructions and remnants in Missouri. Insect Conserv Divers 13:23-35. https://doi.org/10.1111/icad.12365

Legendre P (2014) Interpreting the replacement and richness difference components of beta diversity. Glob Ecol Biogeogr 23:1324-1334. https://doi.org/10.1111/geb.12207

Lenoir J, Gegout JC, Marquet PA, de Ruffray P, Brisse H (2008) A significant upward shift in plant species optimum elevation during the 20th century. Science 320:1768-1771. https://doi.org/10.1126/ science. 1156831

Lichstein JW (2007) Multiple regression on distance matrices: a multivariate spatial analysis tool. Plant Ecol 188:117-131. https://doi. org/10.1007/s11258-006-9126-3

Löffler F, Fartmann T (2017) Effects of landscape and habitat quality on Orthoptera assemblages of pre-alpine calcareous grasslands. Agric Ecosyst Environ 248:71-81. https://doi.org/10.1016/j. agee.2017.07.029

Marini L, Fontana P, Scotton M, Klimek S (2007) Vascular plant and Orthoptera diversity in relation to grassland management and landscape composition in the European Alps. J Appl Ecol 45:361-370. https://doi.org/10.1111/j.1365-2664.2007.01402.x

Marini L, Fontana, Battisti A, Gaston KJ (2009a) Agricultural management, vegetation traits and landscape drive orthopteran and butterfly diversity in a grassland-forest mosaic: a multi-scale approach. Insect Conserv Divers 2:213-220. https://doi.org/10. 1111/j.1752-4598.2009.00053.x

Marini L, Fontana, Klimek S, Battisti A, Gaston KJ (2009b) Impact of farm size and topography on plant and insect diversity of managed grasslands in the Alps. Biol Conserv 142:394-403. https://doi. org/10.1016/j.biocon.2008.10.034
Marini L, Bommarco R, Fontana P, Battisti A (2010) Disentangling effects of habitat diversity and area on orthopteran species with contrasting mobility. Biol Conserv 143:2164-2171. https://doi. org/10.1016/j.biocon.2010.05.029

Marini L, Öckinger E, Battisti A, Bommarco R (2012) High mobility reduces beta-diversity among orthopteran communities -implications for conservation. Insect Conserv Divers 5:37-45. https://doi. org/10.1111/j.1752-4598.2011.00152.x

Matenaar D, Bazelet CS, Hochkirch A (2015) Simple tools for the evaluation of protected areas for the conservation of grasshoppers. Biol Conserv 192:192-199. https://doi.org/10.1016/j.bioco n.2015.09.023

McCain CM, Grytnes J-A (2010) Elevational gradients in species richness. Encyclopedia of life sciences. Wiley, Chichester. https://doi. org/10.1002/9780470015902.a0022548

Miao HT, Liu Y, Shan LY, Wu GL (2018) Linkages of plant-soil interface habitat and grasshopper occurrence of typical grassland ecosystem. Ecol Indic 90:324-333. https://doi.org/10.1016/j.ecoli nd.2018.03.008

Monteiro AT, Fava F, Hiltbrunner E, Della Marianna G, Bocchi S (2011) Assessment of land cover changes and spatial drivers behind loss of permanent meadows in the lowlands of Italian Alps. Landsc Urban Plan 100:287-294. https://doi.org/10.1016/j.landu rbplan.2010.12.015

Moreira X, Abdala-Roberts L, Rasmann S, Castagneyrol B, Mooney KA (2016) Plant diversity effects on insect herbivores and their natural enemies: current thinking, recent findings, and future directions. Curr Opin Insect Sci 14:1-7. https://doi.org/10.1016/j. cois.2015.10.003

Münsch T, Helbing F, Fartmann T (2019) Habitat quality determines patch occupancy of two specialist Lepidoptera species in wellconnected grasslands. J Insect Conserv 23:247-258. https://doi. org/10.1007/s10841-018-0109-1

Nickel H, Hildebrandt J (2003) Auchenorrhyncha communities as indicators of disturbance in grasslands (Insecta, Hemiptera) - a case study from the Elbe flood plains (northern Germany). Agric Ecosyst Environ 98:183-199. https://doi.org/10.1016/S0167 $-8809(03) 00080-\mathrm{X}$

Nickel H, Hildebrandt J (2003b) Auchenorrhyncha communities as indicators of disturbance in grasslands (Insecta, Hemiptera) - a case study from the Elbe flood plains (northern Germany). Agric Ecosyst Environ 98:183-199. https://doi.org/10.1016/S0167 -8809(03)00080-X

Öckinger E, Schweiger O, Crist TO, Debinski DM, Krauss J, Kuussaari M, Petersen JD, Pöyry J, Settele J, Summerville KS, Bommarco R (2010) Life-history traits predict species responses to habitat area and isolation: a cross-continental synthesis. Ecol Lett 13:969-979. https://doi.org/10.1111/j.1461-0248.2010.01487.x

Oksanen J, Blanchet FG, Friendly M, Kindt R, Legendre P, Mcglinn D, Minchin PR, O'hara RB, Simpson GL, Solymos P, Henry M, Stevens H, Szoecs E, Maintainer HW (2019) Package "vegan" title community ecology package. Community Ecol Packag 2:1-297

Perner J, Wytrykush C, Kahmen A, Buchmann N, Egerer I, Creutzburg S, Odat N, Audorff V, Weisser WW (2005) Effects of plant diversity, plant productivity and habitat parameters on arthropod abundance in montane European grasslands. Ecography (Cop) 28:429-442. https://doi.org/10.1111/j.0906-7590.2005.04119.x

Poldini L (1995) La classe Festuco-Brometea nell'Italia nordorientale. Fitosociologia 30:47-50

Poldini L, Oriolo G, Vidali M (2001) Vascular flora of Friuli Venezia Giulia. An annotated catalogne and synonimic index. Stud Geobot 21:3-227

Poniatowski D, Hertenstein F, Raude N, Gottbehüt K, Nickel H, Fartmann T (2018) The invasion of Bromus erectus alters species diversity of vascular plants and leafhoppers in calcareous 
grasslands. Insect Conserv Divers 11:578-586. https://doi. org/10.1111/icad.12302

Poschlod P, WallisDeVries MF (2002) The historical and socioeconomic perspective of calcareous grasslands-lessons from the distant and recent past. Biol Conserv 104:361-376. https://doi. org/10.1016/S0006-3207(01)00201-4

Powell LR, Berg AA, Johnson DL, Warland JS (2007) Relationships of pest grasshopper populations in Alberta, Canada to soil moisture and climate variables. Agric For Meteorol 144:73-84. https://doi. org/10.1016/j.agrformet.2007.01.013

Reinhardt K, Köhler G, Maas S, Detzel P (2005) Low dispersal ability and habitat specificity promote extinctions in rare but not in widespread species: the Orthoptera of Germany. Ecography (Cop) 28:593-602. https://doi.org/10.1111/j.2005.0906-7590.04285.x

Rodríguez-Castañeda G, Dyer LA, Brehm G, Connahs H, Forkner RE, Walla TR (2010) Tropical forests are not flat: how mountains affect herbivore diversity. Ecol Lett 13:1348-1357. https://doi.org /10.1111/j.1461-0248.2010.01525.x

Rösch V, Tscharntke T, Scherber C, Batáry P (2013) Landscape composition, connectivity and fragment size drive effects of grassland fragmentation on insect communities. J Appl Ecol 50:387-394. https://doi.org/10.1111/1365-2664.12056

Samways MJ, Lu S-S (2007) Key traits in a threatened butterfly and its common sibling: implications for conservation. Biodivers Conserv 16:4095-4107. https://doi.org/10.1007/s10531-007-9209-z

Scherber C, Heimann J, Köhler G, Mitschunas N, Weisser WW (2010) Functional identity versus species richness: herbivory resistance in plant communities. Oecologia 163:707-717. https://doi. org/10.1007/s00442-010-1625-1

Schirmel J, Mantilla-Contreras J, Blindow I, Fartmann T (2011) Impacts of succession and grass encroachment on heathland Orthoptera. J Insect Conserv 15:633-642. https://doi.org/10.1007/ s10841-010-9362-7

Schmitz OJ, Rosenblatt AE, Smylie M (2016) Temperature dependence of predation stress and the nutritional ecology of a generalist herbivore. Ecology 97:3119-3130. https://doi.org/10.1002/ecy.1524

Shen G, Yu M, Hu X-S, Mi X, Ren H, Sun I-F, Ma K (2009) Species-area relationships explained by the joint effects of dispersal limitation and habitat heterogeneity. Ecology 90:3033-3041. https ://doi.org/10.1890/08-1646.1

Sundqvist MK, Sanders NJ, Wardle DA (2013) Community and ecosystem responses to elevational gradients: processes, mechanisms, and insights for global change. Annu Rev Ecol Evol Syst 44:261280. https://doi.org/10.1146/annurev-ecolsys-110512-135750

Sykes L, Santini L, Etard A, Newbold T (2020) Effects of rarity form on species' responses to land use. Conserv Biol 34:688-696. https ://doi.org/10.1111/cobi.13419

Taft JB, Dietrich CH (2017) A test of concordance in community structure between leafhoppers and grasslands in the central Tien Shan Mountains. Arthropod Plant Interact 11:843-859. https:// doi.org/10.1007/s11829-017-9539-z
Tasser E, Tappeiner U (2002) Impact of land use changes on mountain vegetation. Appl Veg Sci 5:173-184. https://doi.org/10.1111/ j.1654-109X.2002.tb00547.x

Tattoni C, Ianni E, Geneletti D, Zatelli P, Ciolli M (2017) Landscape changes, traditional ecological knowledge and future scenarios in the Alps: a holistic ecological approach. Sci Total Environ 579:27-36. https://doi.org/10.1016/j.scitotenv.2016.11.075

Torrusio S, Cigliano MM, De Wysiecki ML (2002) Grasshopper (Orthoptera: Acridoidea) and plant community relationships in the Argentine pampas. J Biogeogr 29:221-229. https://doi.org/1 0.1046/j.1365-2699.2002.00663.x

Unsicker SB, Franzke A, Specht J, Köhler G, Linz J, Renker C, Stein C, Weisser WW (2010) Plant species richness in montane grasslands affects the fitness of a generalist grasshopper species. Ecology 91:1083-1091. https://doi.org/10.1890/09-0402.1

Van der Putten WH, Macel M, Visser ME (2010) Predicting species distribution and abundance responses to climate change: why it is essential to include biotic interactions across trophic levels. Philos Trans R Soc B Biol Sci 365:2025-2034. https://doi.org/10.1098/ rstb.2010.0037

van Dijk G (1991) The status of semi-natural grasslands in Europe. The conservation of lowland dry grassland birds in Europe. JNCC Publishers, Peterborough, pp 15-36

Vehviläinen H, Koricheva J, Ruohomäki K (2007) Tree species diversity influences herbivore abundance and damage: meta-analysis of long-term forest experiments. Oecologia 152:287-298. https:// doi.org/10.1007/s00442-007-0673-7

Vidano C (1965) Sulle Forcipata transalpine e cisalpine con descrizione di specie nuove (Homoptera, Typhlocybidae). Boll. di Zool. Agrar. e di Bachic. 37-60

Wagner W (1951) Beitrag zur Phylogenie und Systematik der Cicadellidae (Jassidae) Nord-und Mitteleuropas. Soc Sci Fenn 12(2):15-44

Walcher R, Karrer J, Sachslehner L, Bohner A, Pachinger B, Brandl D, Zaller JG, Arnberger A, Frank T (2017) Diversity of bumblebees, heteropteran bugs and grasshoppers maintained by both: abandonment and extensive management of mountain meadows in three regions across the Austrian and Swiss Alps. Landsc Ecol 32:1937-1951. https://doi.org/10.1007/s10980-017-0556-1

Zhu H, Qu Y, Zhang D, Li J, Wen M, Wang D, Ren B (2017) Impacts of grazing intensity and increased precipitation on a grasshopper assemblage (Orthoptera: Acrididae) in a meadow steppe. Ecol Entomol 42:458-468. https://doi.org/10.1111/een.12403

Willott SJ, Hassall M (1998) Life-history responses of British grasshoppers (Orthoptera: Acrididae) to temperature change. Funct Ecol 12:232-241. https://doi.org/10.1046/j.1365-2435.1998.00180.x

Publisher's Note Springer Nature remains neutral with regard to jurisdictional claims in published maps and institutional affiliations. 